\title{
Lewis base-assisted Lewis acid-catalyzed selective alkene formation via alcohol dehydration and synthesis of 2-cinnamyl-1,3-dicarbonyl compounds from 2-aryl-3,4-dihydropyrans
}

\author{
Changhui Liu a, Bin Pana, Yanlong Gu a,b,* \\ ${ }^{a}$ Key Laboratory of Material Chemistry for Energy Conversion and Storage, Ministry of Education, School of Chemistry and Chemical Engineering, Hubei \\ Key Laboratory of Material Chemistry and Service Failure, Huazhong University of Science and Technology, Wuhan 430074, Hubei, China \\ ${ }^{\mathrm{b}}$ State Key Laboratory for Oxo Synthesis and Selective Oxidation, Lanzhou Institute of Chemical Physics, Chinese Academy of Sciences, Lanzhou 730000 , \\ Gansu, China
}

\section{A R T I C L E I N F O}

\section{Article history:}

Received 5 February 2016

Accepted 15 March 2016

Published 5 June 2016

\section{Keywords:}

Synergistic catalysis

Acid-base catalysis

Dehydration of alcohol

2-Cinnamyl-1,3-dicarbonyl compound

Homogeneous catalysis

\begin{abstract}
A B S T R A C T
Acid-catalyzed dehydration of alcohols has been widely employed for the synthesis of alkenes. However, activated alcohols when employed as substrates in dehydration reactions are often plagued by the lack of alkene selectivity. In this work, the reaction system can be significantly improved through enhancing the performance of Lewis acid catalysts in the dehydration of activated alcohols by combining with a Lewis base. Observations of the reaction mechanism revealed that the Lewis base component might have changed the reaction rate order. Although both the principal and side reaction rates decreased, the effect was markedly more observed on the latter reaction. Therefore, the selectivity of the dehydration reaction was improved. On the basis of this observation, a new route to synthesize 2-cinnamyl-1,3-dicarbonyl compounds was developed by using 2-aryl-3,4dihydropyran as a starting substrate in the presence of a Lewis acid/Lewis base combined catalyst system.
\end{abstract}

(C) 2016, Dalian Institute of Chemical Physics, Chinese Academy of Sciences. Published by Elsevier B.V. All rights reserved.

\section{Introduction}

Dehydration of alcohols has been widely studied and employed in the manufacture of olefins together with other valuable intermediates [1]. In the chemical industry, $15 \%$ of the global styrene production is obtained through the dehydration of 1-phenylethanol-the byproduct in the propylene oxide synthesis from ethylbenzene hydroperoxide [2]. Therefore, this reaction has been extensively studied [3-8]. Organic chemists often use 1-arylethanol as a substrate to synthesize 1-arylethylene, which is a useful synthon [9-13]. One reason why 1 -arylethylene is an attractive compound is because of the abundant accessibility of its starting substrate, making the 1-arylethanol dehydration reaction of significant industrial importance [14]. Although acid catalysts are well-known to be effective for promoting such reactions, when activated alcohols are used, there is a degree of difficulty-because of selectivity to form undesirable by-products - to find a suitable catalyst system that forms 1-arylethylene in a satisfactory yield [15]. To date, there is no current established catalyst system regarding the dehydration of 1-phenylethanol to yield 1-arylethylene. The reasons are two-fold: (1) typical industrial practices prefer the use of solid catalysts; the reported solid acids for the dehydration of 1-phenylethanol are generally associated sophisticated

\footnotetext{
* Corresponding author. Tel: +86-27-87543732; Fax: +86-27-87544532; E-mail: klgyl@hust.edu.cn This work was supported by the National Natural Science Foundation of China (21173089 and 21373093), the Fundamental Research Funds for the Central Universities of China (2014ZZGH019), and the Cooperative Innovation Center of Hubei Province. DOI: 10.1016/S1872-2067(15)61084-1 | http://www.sciencedirect.com/science/journal/18722067 | Chin. J. Catal., Vol. 37, No. 6, June 2016
} 
operational procedures [16,17]; however, synthetic chemists are not typically familiar with heterogeneous catalysis chemistry and therefore are unable to influence this reaction; (2) to facilitate industrial production, most reported systems for the dehydration of 1-phenylethanol operate in a fixed-bed reactor at high temperatures $\left(>250{ }^{\circ} \mathrm{C}\right)[18]$; however, organic compounds with functional substituent groups may not be tolerable at such high temperatures. Although liquid-phase dehydration of 1-phenylethanol has also been investigated using either homogeneous acids [19] or heterogeneous solid acids [20,21], to concomitantly extend the knowledge of this relatively simple reaction to the dehydration of complex alcohol substrates requires a separate model reaction. Therefore, the requirement remains to develop an efficient liquid-phase system for 1-arylethylene production through the dehydration of 1-arylethanol.

Additionally, designing catalysts to achieve tailored properties is currently an area of significant investigation in both catalysis and organic synthesis [22-25]. Various catalyst combinations, such as Lewis acid/Brönsted base [26-28], Lewis acid/Lewis base [29], Lewis acid/Brönsted acid [30-32], Lewis acid/Lewis acid [33], and transition metal/Lewis acid [34,35] have been developed to provide unique catalytic activities. Such combinations not only offer new routes to synthesize bi-functional catalysts [36-41], but also allow newly designed bi-functional catalysts to circumvent technical difficulties encountered in such applications [42-45]. Herein, we introduce a Lewis base-assisted Lewis acid-catalyzed selective alkene formation through alcohol dehydration. This combined acid/base system is particularly effective for the synthesis of 1-arylethylene from activated 1-arylethanol. On the basis of this observation, a new method for the synthesis of 2-cinnarmyl-1,3-dicarbonyl compounds from 2-aryl-3,4-dihydropyrans was also developed by using an analogous acid/base combined catalyst system.

\section{Experimental}

\subsection{General}

Infrared spectra were recorded on a Bruker EQUINOX 55 spectrometer using $\mathrm{KBr}$ pellets or neat liquid technology. ${ }^{1} \mathrm{H}$ and ${ }^{13} \mathrm{C}$ nuclear magnetic resonance (NMR) spectra were recorded on a Bruker AV-400 or 600. Chemical shifts were expressed in ppm relative to solvated $\mathrm{Me}_{4} \mathrm{Si}$. All chemicals used were of reagent grade and were used as received without further purification. All reactions were conducted in a $10 \mathrm{~mL}$ V-type flask equipped with triangle magnetic stirring.

\subsection{A typical alcohol dehydration procedure}

In a typical reaction, alcohol $(0.4 \mathrm{mmol})$ was mixed with $\mathrm{AlCl}_{3}$ (0.02 mmol, $\left.5 \mathrm{~mol} \%\right)$ and triphenylphosphine $\left(\mathrm{PPh}_{3}, 0.02\right.$ mmol, $5 \mathrm{~mol} \%)$ in nitromethane $(1.0 \mathrm{~mL})$. Thereafter the mixture was stirred at $80^{\circ} \mathrm{C}$ for $2 \mathrm{~h}$. After the reaction, the mixture was cooled to room temperature, and the product was isolated using preparative thin layer chromatography (TLC, eluting solution: petroleum ether/ethyl acetate, $5 / 1(\mathrm{v} / \mathrm{v}))$. Tests for substrate scope were all performed with an analogous procedure.

\subsection{A typical ring-opening reaction procedure for 2-aryl-3,4-dihydropyrans}

In a typical reaction, dihydropyran $(0.20 \mathrm{mmol})$ was mixed with $\mathrm{I}_{2}$ (0.01 mmol, $5 \mathrm{~mol} \%$ ) and $\mathrm{PPh}_{3}(0.01 \mathrm{mmol}, 5 \mathrm{~mol} \%)$ in nitromethane $(1.0 \mathrm{~mL})$. The mixture was then stirred at $80{ }^{\circ} \mathrm{C}$ for $1 \mathrm{~h}$. After the reaction, the mixture was cooled to room temperature, and the product isolated using preparative TLC (eluting solution: petroleum ether/ethyl acetate, $5 / 1$ or $3 / 1$ $(\mathrm{v} / \mathrm{v})$ ). Tests for substrate scope were all performed with an analogous procedure.

(E)-3-(3-(p-Tolyl)allyl)pentane-2,4-dione (a mixture of enol and ketone form) (6a): colorless oil. ${ }^{1} \mathrm{H}$ NMR (400 $\mathrm{MHz}, \mathrm{CDCl}_{3}$, TMS, $\left.25^{\circ} \mathrm{C}\right) \delta=16.78(\mathrm{~s}, 0.36 \mathrm{H}), 7.29-7.18(\mathrm{~m}, 2 \mathrm{H}), 7.15-7.05$ (m, 2H), 6.36 (dd, $J=42.9,15.9 \mathrm{~Hz}, 1 \mathrm{H}), 6.21-5.94(\mathrm{~m}, 1 \mathrm{H}), 3.79$ $(\mathrm{t}, J=7.3 \mathrm{~Hz}, 0.5 \mathrm{H}), 3.14(\mathrm{~d}, J=5.3 \mathrm{~Hz}, 0.96 \mathrm{H}), 2.73(\mathrm{t}, J=7.2 \mathrm{~Hz}$, 1.08H), 2.32 (s, 3H), $2.20(\mathrm{~s}, 3 \mathrm{H}), 2.15(\mathrm{~s}, 3 \mathrm{H}) .{ }^{13} \mathrm{C}$ NMR $(100$ $\left.\mathrm{MHz}, \mathrm{CDCl}_{3}, 25^{\circ} \mathrm{C}\right) \delta=203.7,191.6,137.4,137.2,134.3,134.0$, 132.6, 129.9, 129.3, 129.2, 126.6, 126.1, 126.0, 124.4, 107.6, 68.4, 31.6, 30.9, 30.5, 29.4, 23.1, 21.1. IR (KBr) v: 2956, 2923, 1725, 1702, 1607, 1513, 1420, 1358, 1282, 1151, 970, 797, 505 $\mathrm{cm}^{-1}$. HRMS $\mathrm{m} / z$ (ESI) calculated for $\mathrm{C}_{15} \mathrm{H}_{18} \mathrm{NaO}_{2}[\mathrm{M}+\mathrm{Na}]^{+}$ 253.1204 found 253.1224 .

(E)-Methyl 2-acetyl-5-(4-fluorophenyl)hex-4-enoate (6e): colorless oil. ${ }^{1} \mathrm{H}$ NMR ( $\left.400 \mathrm{MHz}, \mathrm{CDCl}_{3}, \mathrm{TMS}, 25^{\circ} \mathrm{C}\right) \delta=7.33$ (dd, $J=8.7,5.4 \mathrm{~Hz}, 2 \mathrm{H}), 6.99(\mathrm{t}, J=8.7 \mathrm{~Hz}, 2 \mathrm{H}), 6.03(\mathrm{~d}, J=1.6 \mathrm{~Hz}$, $1 \mathrm{H}), 3.76$ (s, 3H), 3.44 (s, 1H), 2.65 (ddd, $J=25.1,15.7,12.7 \mathrm{~Hz}$, $3 \mathrm{H}), 2.51-2.40(\mathrm{~m}, 2 \mathrm{H}), 1.37(\mathrm{~s}, 3 \mathrm{H}) .{ }^{13} \mathrm{C} \mathrm{NMR}\left(150 \mathrm{MHz}, \mathrm{CDCl}_{3}\right.$, $\left.25^{\circ} \mathrm{C}\right) \delta=176.5,162.9,161.2,137.2,133.7,126.7,126.7,121.0$, 115.1, 115.0, 68.8, 51.9, 47.5, 40.7, 28.4, 27.1. ${ }^{19} \mathrm{~F}$ NMR (565 $\left.\mathrm{MHz}, \mathrm{CDCl}_{3}, 25^{\circ} \mathrm{C}\right) \delta=-115.8$. IR (KBr) v: 3523, 2957, 2925, 1720, 1511, 1438, 1381, 1229, 1168, 1027, 819, $540 \mathrm{~cm}^{-1}$. HRMS $m / z$ (ESI) calculated for $\mathrm{C}_{15} \mathrm{H}_{17} \mathrm{FNaO}_{3}[\mathrm{M}+\mathrm{Na}]^{+}$ 287.1059 found 287.1067.

(E)-Methyl 2-acetyl-5-(4-chlorophenyl)hex-4-enoate (6f) [5]: colorless oil. ${ }^{1} \mathrm{H}$ NMR (400 MHz, $\left.\mathrm{CDCl}_{3}, \mathrm{TMS}, 25^{\circ} \mathrm{C}\right) \delta=$ 7.32-7.24 (m, 4H), 6.08 (dd, $J=2.9,1.6 \mathrm{~Hz}, 1 \mathrm{H}), 3.76(\mathrm{~s}, 3 \mathrm{H})$, 3.42 (s, 1H), 2.74-2.56 (m, 3H), 2.52-2.38 (m, 2H), 1.37 (s, 3H). ${ }^{13} \mathrm{C} \mathrm{NMR}\left(150 \mathrm{MHz}, \mathrm{CDCl}_{3}, 25^{\circ} \mathrm{C}\right) \delta=207.0,176.4,139.5,133.6$, 132.8, 128.4, 126.4, 121.7, 68.8, 52.0, 47.5, 40.4, 28.4, 27.2.

(E)-2-Pivaloyl-5-(p-tolyl)pent-4-enenitrile (6g): colorless oil. ${ }^{1} \mathrm{H}$ NMR $\left(600 \mathrm{MHz}, \mathrm{CDCl}_{3}\right.$, TMS, $\left.25^{\circ} \mathrm{C}\right) \delta=7.26-7.20(\mathrm{~m}, 3 \mathrm{H})$, $7.12(\mathrm{~d}, J=7.6 \mathrm{~Hz}, 2 \mathrm{H}), 6.50(\mathrm{~d}, J=15.7 \mathrm{~Hz}, 1 \mathrm{H}), 6.12-5.99(\mathrm{~m}$, 1H), 3.91 (t, $J=7.4 \mathrm{~Hz}, 1 \mathrm{H}), 2.75(\mathrm{dd}, J=11.5,7.1 \mathrm{~Hz}, 2 \mathrm{H}), 2.33$ (s, 3H), 1.25-1.22 (m, 9H). ${ }^{13} \mathrm{C}$ NMR $\left(150 \mathrm{MHz}, \mathrm{CDCl}_{3}, 25^{\circ} \mathrm{C}\right) \delta=$ 204.9, 137.8, 134.5, 133.6, 129.3, 126.2, 125.5, 122.3, 117.0, 45.6, 37.2, 33.4, 26.0, 21.2. IR (KBr) v: 2968, 2928, 2242, 2206, $1784,1721,1513,1475,1370,1282,1175,1056,968,795,507$ $\mathrm{cm}^{-1}$. HRMS $\mathrm{m} / z$ (ESI) calculated for $\mathrm{C}_{17} \mathrm{H}_{21} \mathrm{NNaO}[\mathrm{M}+\mathrm{Na}]^{+}$ 278.1521 found 278.1531 .

(E)-Ethyl 2-(4-methoxybenzoyl)-5-(4-methoxyphenyl)pent4-enoate (6h): colorless oil. ${ }^{1} \mathrm{H}$ NMR $\left(600 \mathrm{MHz}, \mathrm{CDCl}_{3}\right.$, TMS, 25 $\left.{ }^{\circ} \mathrm{C}\right) \delta=8.00(\mathrm{~d}, J=8.9 \mathrm{~Hz}, 2 \mathrm{H}), 7.23(\mathrm{~d}, J=8.6 \mathrm{~Hz}, 2 \mathrm{H}), 6.94(\mathrm{~d}, J$ 
$=8.9 \mathrm{~Hz}, 2 \mathrm{H}), 6.81(\mathrm{~d}, J=8.7 \mathrm{~Hz}, 2 \mathrm{H}), 6.42(\mathrm{~d}, J=15.7 \mathrm{~Hz}, 1 \mathrm{H})$, 6.19-5.92 (m, 1H), $4.40(\mathrm{t}, J=7.2 \mathrm{~Hz}, 1 \mathrm{H}), 4.21-4.07(\mathrm{~m}, 2 \mathrm{H})$, $3.87(\mathrm{~s}, 3 \mathrm{H}), 3.78(\mathrm{~s}, 3 \mathrm{H}), 2.97-2.76(\mathrm{~m}, 2 \mathrm{H}), 1.17(\mathrm{t}, J=7.1,3 \mathrm{H})$. ${ }^{13} \mathrm{C}$ NMR $\left(150 \mathrm{MHz}, \mathrm{CDCl}_{3}, 25^{\circ} \mathrm{C}\right) \delta=192.9,169.7,163.9,159.0$, $131.9,131.1,130.0,129.2,127.3,124.1,113.9,113.9,61.4,55.5$, $55.3,54.3,32.5,14.1$. IR (KBr) $v: 2933,2839,1735,1677,1602$, $1511,1421,1252,1175,1031,968,842 \mathrm{~cm}^{-1}$. HRMS $\mathrm{m} / z$ (ESI) calculated for $\mathrm{C}_{22} \mathrm{H}_{24} \mathrm{NaO}_{5}[\mathrm{M}+\mathrm{Na}]+391.1521$ found 391.1518 .

(E)-Methyl 2-acetyl-5-(4-(tert-butyl)phenyl)pent-4-enoate (6i): colorless oil. ${ }^{1} \mathrm{H}$ NMR (600 MHz, $\mathrm{CDCl}_{3}$, TMS, $\left.25^{\circ} \mathrm{C}\right) \delta=$ 7.32 (d, $J=8.4 \mathrm{~Hz}, 2 \mathrm{H}$ ), 7.26 (d, $J=8.3 \mathrm{~Hz}, 2 \mathrm{H}$ ), 6.44 (d, $J=15.8$ $\mathrm{Hz}, 1 \mathrm{H}), 6.07(\mathrm{dt}, J=15.7,7.2 \mathrm{~Hz}, 1 \mathrm{H}), 3.74(\mathrm{~s}, 3 \mathrm{H}), 3.60(\mathrm{t}, J=$ $7.4 \mathrm{~Hz}, 1 \mathrm{H}), 2.74(\mathrm{dd}, J=10.3,4.4 \mathrm{~Hz}, 2 \mathrm{H}), 2.25$ (s, 3H), 1.30 (s, 9H). ${ }^{13} \mathrm{C}$ NMR $\left(150 \mathrm{MHz}, \mathrm{CDCl}_{3}, 25^{\circ} \mathrm{C}\right) \delta=202.5,169.7,150.6$, 134.2, 132.6, 125.9, 125.5, 124.8, 59.5, 52.5, 34.6, 31.6, 31.3, 29.3. IR (KBr) v: 2959, 1745, 1719, 1436, 1361, 1266, 1217, 1152, 970, 803, $560 \mathrm{~cm}^{-1}$. HRMS $\mathrm{m} / z$ (ESI) calculated for $\mathrm{C}_{18} \mathrm{H}_{24} \mathrm{NaO}_{3}[\mathrm{M}+\mathrm{Na}]+311.1623$ found 311.1643.

(E)-2-Methoxyethyl 2-acetyl-5-(p-tolyl)pent-4-enoate (6j): colorless oil. ${ }^{1} \mathrm{H}$ NMR $\left(400 \mathrm{MHz}, \mathrm{CDCl}_{3}, \mathrm{TMS}, 25^{\circ} \mathrm{C}\right) \delta=7.21(\mathrm{~d}, J$ $=7.8 \mathrm{~Hz}, 2 \mathrm{H}), 7.09$ (d, $J=7.8 \mathrm{~Hz}, 2 \mathrm{H}), 6.43(\mathrm{~d}, J=15.8 \mathrm{~Hz}, 1 \mathrm{H})$, 6.24-5.89 (m, 1H), 4.37-4.19 (m, 2H), $3.63(\mathrm{t}, J=7.3 \mathrm{~Hz}, 1 \mathrm{H})$, $3.57(\mathrm{t}, J=4.6 \mathrm{~Hz}, 2 \mathrm{H}), 3.33(\mathrm{~d}, J=0.8 \mathrm{~Hz}, 3 \mathrm{H}), 2.74(\mathrm{t}, J=7.3 \mathrm{~Hz}$, $2 \mathrm{H}), 2.31$ (s, 3H), 2.26 (s, 3H). ${ }^{13} \mathrm{C}$ NMR (100 MHz, $\left.\mathrm{CDCl}_{3}, 25^{\circ} \mathrm{C}\right)$ $\delta=202.3,169.3,137.2,134.2,132.6,129.2,126.1,124.5,70.2$, 64.2, 59.5, 58.9, 31.6, 29.2, 21.1. IR (KBr) v: 3024, 2925, 1742, $1717,1513,1450,1361,1129,1032,971,793 \mathrm{~cm}^{-1}$. HRMS m/z (ESI) calculated for $\mathrm{C}_{17} \mathrm{H}_{22} \mathrm{NaO}_{4}[\mathrm{M}+\mathrm{Na}]^{+} 313.1416$ found 313.1422.

(E)-Ethyl 2-acetyl-5-(4-fluorophenyl)hex-4-enoate $\quad(6 \mathbf{k})$ : colorless oil, ${ }^{1} \mathrm{H}$ NMR ( $\left.600 \mathrm{MHz}, \mathrm{CDCl}_{3}, \mathrm{TMS}, 25^{\circ} \mathrm{C}\right) \delta=7.33$ (dd, $J=5.5,3.2 \mathrm{~Hz}, 2 \mathrm{H}), 6.99(\mathrm{~s}, 2 \mathrm{H}), 6.03(\mathrm{~s}, 1 \mathrm{H}), 4.28-4.16(\mathrm{~m}, 2 \mathrm{H})$, $3.51(\mathrm{~s}, 1 \mathrm{H}), 2.62$ (ddd, $J=22.5,17.3,10.3 \mathrm{~Hz}, 3 \mathrm{H}), 2.44(\mathrm{t}, J=$ $18.8 \mathrm{~Hz}, 2 \mathrm{H}), 1.40-1.35$ (m, 3H), $1.33-1.28(\mathrm{~m}, 4 \mathrm{H}) .{ }^{13} \mathrm{C}$ NMR $\left(150 \mathrm{MHz}, \mathrm{CDCl}_{3}, 25^{\circ} \mathrm{C}\right) \delta=202.6,169.4,139.4,139.4,136.7$, $129.4,129.3,127.3,127.2,123.3,122.9,115.2,115.1,115.0$, $114.9,61.5,59.5,29.2,27.5,16.1,14.1 .{ }^{19} \mathrm{~F}$ NMR $(565 \mathrm{MHz}$, $\mathrm{CDCl}_{3}, 25^{\circ} \mathrm{C}$ ) $\delta=-115.7,-116.0,-116.1$. IR (KBr) v: 2983, 2933, 1740, 1716, 1601, 1509, 1363, 1228, 1158, 1097, 969, 849 $\mathrm{cm}^{-1}$. HRMS $\mathrm{m} / z$ (ESI) calculated for $\mathrm{C}_{16} \mathrm{H}_{19} \mathrm{FNaO}_{3}[\mathrm{M}+\mathrm{Na}]^{+}$ 301.1216 found 301.1213 .

(E)-Ethyl 2-acetyl-5-(4-fluorophenyl)pent-4-enoate (61): colorless oil. ${ }^{1} \mathrm{H}$ NMR $\left(400 \mathrm{MHz}, \mathrm{CDCl}_{3}\right.$, TMS, $\left.25^{\circ} \mathrm{C}\right) \delta=7.27$ (td, $J=5.4,2.6 \mathrm{~Hz}, 2 \mathrm{H}), 6.97(\mathrm{t}, J=8.7 \mathrm{~Hz}, 2 \mathrm{H}), 6.39(\mathrm{t}, J=17.8 \mathrm{~Hz}$, $1 \mathrm{H}), 6.15-5.96(\mathrm{~m}, 1 \mathrm{H}), 4.33-4.06(\mathrm{~m}, 2 \mathrm{H}), 3.58(\mathrm{t}, J=7.3 \mathrm{~Hz}$, $1 \mathrm{H}), 2.73(\mathrm{t}, J=7.1 \mathrm{~Hz}, 2 \mathrm{H}), 2.26(\mathrm{~s}, 3 \mathrm{H}), 1.26(\mathrm{t}, \mathrm{J}=7.1 \mathrm{~Hz}, 3 \mathrm{H})$. ${ }^{13} \mathrm{C}$ NMR $\left(100 \mathrm{MHz}, \mathrm{CDCl}_{3}, 25^{\circ} \mathrm{C}\right) \delta=202.4,169.2,163.4,161.0$, $133.1,131.5,129.6,128.6,127.7,127.6,127.5,127.4,125.5$, $115.5,115.5,115.3,115.2,61.5,59.5,31.4,29.2,14.1 .{ }^{19} \mathrm{~F}$ NMR (377 MHz, $\mathrm{CDCl}_{3}, 25^{\circ} \mathrm{C}$ ) $\delta=-114.8,-114.9,-115.4$. IR (KBr) v: 3521, 2963, 2928, 1715, 1511, 1380, 1229, 1181, 1101, 1034, $818,539 \mathrm{~cm}^{-1}$. HRMS $\mathrm{m} / z$ (ESI) calculated for $\mathrm{C}_{15} \mathrm{H}_{17} \mathrm{FNaO}_{3}[\mathrm{M}$ $+\mathrm{Na}]^{+} 287.1059$ found 287.1071.

\section{Results and discussion}

Initially, dehydration of $\mathbf{1 a}$ to form alkene $\mathbf{2 a}$ was investi- gated. The reaction was performed in nitromethane $\left(\mathrm{CH}_{3} \mathrm{NO}_{2}\right)$ at $80^{\circ} \mathrm{C}$. As shown in Table 1 , in the presence of $\mathrm{AlCl}_{3}$ catalyst, only trace amounts of the desired product $2 \mathbf{a}$ was detected with the starting material selectively converting to the dimerization product 3a in abundance (entry 1). Under identical conditions, $\mathrm{FeCl}_{3} \cdot 6 \mathrm{H}_{2} \mathrm{O}$ was shown to be a less effective catalyst for the dehydration of 1a (entry 2). Toluenesulfonic acid ( $p$-TSA) was also observed to be unreactive for this reaction (entry 3). To circumvent issues with reactivity, we studied the reaction system in the presence of an additive. It was evidenced that the addition of $5 \mathrm{~mol} \%$ of $\mathrm{PPh}_{3}$ in the presence of the $\mathrm{AlCl}_{3}$ Lewis acid yielded an increase in the desired product to 93\% (entry 4). However, $\mathrm{PPh}_{3}$ cannot catalyze this transformation alone and requires the presence of a Lewis acid (entry 5). Alternative combinations of Lewis bases or Brönsted bases were also examined (entries 6-12). Tributyl phosphine ( $\left.\mathrm{PBu}_{3}\right)$ and 1,2-bis(diphenylphosphino)ethane (DPPE) showed significantly improved efficiency compared with pyridine, $o$-phenanthroline and 1,4-diazabicyclo[2.2.2] octane (DABCO). To reduce cost, $\mathrm{PPh}_{3}$ was used henceforth in our study. $\mathrm{AlCl}_{3}$ was observed to be the most efficient Lewis acid, as when subjecting the reaction to other Lewis acids, such as $p$-TSA, $\mathrm{FeCl}_{4} \cdot 6 \mathrm{H}_{2} \mathrm{O}$ or $\mathrm{I}_{2}$ in the presence of $\mathrm{PPh}_{3}$ a dramatic drop in the conversion of $1 \mathbf{1 a}$ resulted (entries 13-15). Further investigations were also conducted as a function of the solvent. Among the various solvents tested, nitromethane clearly yielded more of the desired product, with toluene, acetonitrile and ethanol observed to be less efficient (64\%-76\%) (entries 16-18). Increasing the reaction temperature from 80 to $100{ }^{\circ} \mathrm{C}$ resulted in a decrease of the reaction selectivity, even though the reaction time was halved (entry 19). The test matrix revealed the optimal conditions to

\section{Table 1}

Dehydration of 1a over various catalyst systems.

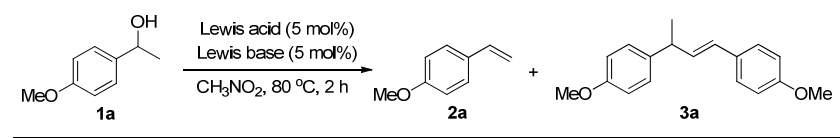

\begin{tabular}{|c|c|c|c|c|c|c|}
\hline \multirow{2}{*}{ Entry } & \multirow{2}{*}{ Acid } & \multirow{2}{*}{ Base } & \multirow{2}{*}{ Solvent } & \multirow{2}{*}{$\begin{array}{c}\text { Conv. of } \\
\text { 1a }(\%)\end{array}$} & \multicolumn{2}{|c|}{ Yield a (\%) } \\
\hline & & & & & $2 a$ & $3 a$ \\
\hline 1 & $\mathrm{AlCl}_{3}$ & - & $\mathrm{CH}_{3} \mathrm{NO}_{2}$ & 97 & 5 & 91 \\
\hline 2 & $\mathrm{FeCl}_{3} \cdot 6 \mathrm{H}_{2} \mathrm{O}$ & - & $\mathrm{CH}_{3} \mathrm{NO}_{2}$ & 21 & 2 & 1 \\
\hline 3 & $p$-TSA & - & $\mathrm{CH}_{3} \mathrm{NO}_{2}$ & 15 & trace & trace \\
\hline 4 & $\mathrm{AlCl}_{3}$ & $\mathrm{PPh}_{3}$ & $\mathrm{CH}_{3} \mathrm{NO}_{2}$ & 95 & 93 & trace \\
\hline 5 & - & $\mathrm{PPh}_{3}$ & $\mathrm{CH}_{3} \mathrm{NO}_{2}$ & 0 & 0 & 0 \\
\hline 6 & $\mathrm{AlCl}_{3}$ & $\mathrm{NEt}_{3}$ & $\mathrm{CH}_{3} \mathrm{NO}_{2}$ & 71 & 52 & trace \\
\hline 7 & $\mathrm{AlCl}_{3}$ & Pyridine & $\mathrm{CH}_{3} \mathrm{NO}_{2}$ & 43 & 10 & trace \\
\hline 8 & $\mathrm{AlCl}_{3}$ & $o$-Phenanthroline & $\mathrm{CH}_{3} \mathrm{NO}_{2}$ & 62 & 0 & 35 \\
\hline 9 & $\mathrm{AlCl}_{3}$ & $\mathrm{P}(0) \mathrm{Ph}_{3}$ & $\mathrm{CH}_{3} \mathrm{NO}_{2}$ & 41 & 5 & 47 \\
\hline 10 & $\mathrm{AlCl}_{3}$ & DABCO & $\mathrm{CH}_{3} \mathrm{NO}_{2}$ & 29 & trace & 3 \\
\hline 11 & $\mathrm{AlCl}_{3}$ & $\mathrm{PBu}_{3}$ & $\mathrm{CH}_{3} \mathrm{NO}_{2}$ & 91 & 90 & trace \\
\hline 12 & $\mathrm{AlCl}_{3}$ & DPPE & $\mathrm{CH}_{3} \mathrm{NO}_{2}$ & 89 & 85 & 2 \\
\hline 13 & $p$-TSA & $\mathrm{PPh}_{3}$ & $\mathrm{CH}_{3} \mathrm{NO}_{2}$ & 12 & trace & trace \\
\hline 14 & $\mathrm{FeCl}_{3} \cdot 6 \mathrm{H}_{2} \mathrm{O}$ & $\mathrm{PPh}_{3}$ & $\mathrm{CH}_{3} \mathrm{NO}_{2}$ & 18 & trace & tra \\
\hline 15 & $\mathrm{I}_{2}$ & $\mathrm{PPh}_{3}$ & $\mathrm{CH}_{3} \mathrm{NO}_{2}$ & 26 & 15 & trace \\
\hline 16 & $\mathrm{AlCl}_{3}$ & $\mathrm{PPh}_{3}$ & $\mathrm{PhMe}$ & 81 & 64 & 2 \\
\hline 17 & $\mathrm{AlCl}_{3}$ & $\mathrm{PPh}_{3}$ & $\mathrm{CH}_{3} \mathrm{CN}$ & 87 & 76 & trace \\
\hline 18 & $\mathrm{AlCl}_{3}$ & $\mathrm{PPh}_{3}$ & EtOH & 19 & 8 & trace \\
\hline $19^{b}$ & $\mathrm{AlCl}_{3}$ & $\mathrm{PPh}_{3}$ & $\mathrm{CH}_{3} \mathrm{NO}_{2}$ & 98 & 79 & trace \\
\hline
\end{tabular}

Reaction conditions: $0.4 \mathrm{mmol}$, Lewis acid $0.02 \mathrm{mmol}$, Lewis base 0.02 mmol, solvent $1.0 \mathrm{~mL}, 80^{\circ} \mathrm{C}, 2 \mathrm{~h}$.

${ }^{\mathrm{a}} \mathrm{GC}$ yield. ${ }^{\mathrm{b}} 100^{\circ} \mathrm{C}, 1 \mathrm{~h}$. 
Table 2

Substrate scope of $\mathrm{AlCl}_{3} / \mathrm{PPh}_{3}$-catalyzed alcohol dehydration reactions for the synthesis of alkenes.

\begin{tabular}{|c|c|c|c|c|}
\hline & $\mathrm{OH}$ & & & $D^{2}$ \\
\hline & & $\mathrm{CH}_{3} \mathrm{~N}$ & $\mathrm{C}, 2 \mathrm{~h}$ & $2 b-2 m$ \\
\hline Entry & $\mathrm{R}^{1}$ & $\mathrm{R}^{2}$ & Product & Isolated yield (\%) \\
\hline 1 & $4-\mathrm{Me}$ & $\mathrm{H}$ & $2 b$ & 89 \\
\hline 2 & $4-F$ & $\mathrm{H}$ & 2c & 78 \\
\hline 3 & $4-\mathrm{Br}$ & $\mathrm{H}$ & 2d & 79 \\
\hline 4 & $4-{ }^{-t} \mathrm{Bu}$ & $\mathrm{H}$ & $2 e$ & 88 \\
\hline 5 & $4-\mathrm{C}_{6} \mathrm{H}_{5}$ & $\mathrm{H}$ & $2 f$ & 92 \\
\hline 6 & 4-nAmyl & $\mathrm{H}$ & $2 g$ & 91 \\
\hline 7 & $2-\mathrm{Cl}$ & $\mathrm{H}$ & $2 \mathrm{~h}$ & 73 \\
\hline 8 & $3-\mathrm{Br}$ & $\mathrm{H}$ & $2 \mathbf{i}$ & 81 \\
\hline 9 & $\mathrm{H}$ & $\mathrm{Me}$ & $2 j$ & 97 \\
\hline 10 & $3,4-(\mathrm{OMe})_{2}$ & $\mathrm{Me}$ & $2 k$ & 97 \\
\hline 11 & & & 21 & 90 \\
\hline 12 & & & $2 m$ & 89 \\
\hline
\end{tabular}

Reaction conditions: alcohol $0.4 \mathrm{mmol}, \mathrm{AlCl}_{3} 5 \mathrm{~mol} \%, \mathrm{PPh}_{3} 5 \mathrm{~mol} \%$, $\mathrm{CH}_{3} \mathrm{NO}_{2} 1.0 \mathrm{ml}, 80^{\circ} \mathrm{C}, 2 \mathrm{~h}$.

be: $5 \mathrm{~mol} \%$ of $\mathrm{AlCl}_{3}$ and $5 \mathrm{~mol} \%$ of $\mathrm{PPh}_{3}$ in nitromethane at 80 ${ }^{\circ} \mathrm{C}$ for $2 \mathrm{~h}$.

Using the optimized reaction conditions, the substrate scope was probed, and the results are shown in Table 2. First, the $\alpha$-phenylethanols bearing para-substituted groups were studied (entries 1-6). It was found that halide, alkyl and aryl group substituted alcohols readily yielded their corresponding olefins. The presence of an electron-donating group in the phenyl ring facilitated, to some degree, progress of the reaction (entries 1, 4 and 6). However, when para- $\mathrm{NO}_{2}$-substituted $\alpha$-phenylethanol was used, only unreacted starting material was recovered. The stability of the carbocation may be ascribed to the negative effect of the electron-withdrawing group. Furthermore, ortho- and meta-substituted $\alpha$-phenylethanols were also tested (entries 7 and 8), with their corresponding desired products forming with unsurprisingly good yields. It should be noted that in addition to selected terminal olefins, internal alkenes and cycloalkenes could also be synthesized using this method (entries 9-12). As shown in Scheme 1, tertiary alcohols $\mathbf{1 b}$ and $\mathbf{1 c}$ can also be selectively converted to $\mathbf{2 n}$ and $2 \mathbf{o}$ without the formation of any side-product. Thus the present protocol offers an efficient route to synthesize complex alkene derivatives.

However, the mechanisms by which the two catalysts cooperatively affect the catalysis remain to be delineated. The $\mathrm{AlCl}_{3}$-catalyzed dehydration of $\mathbf{1 a}$ suffered mainly from the

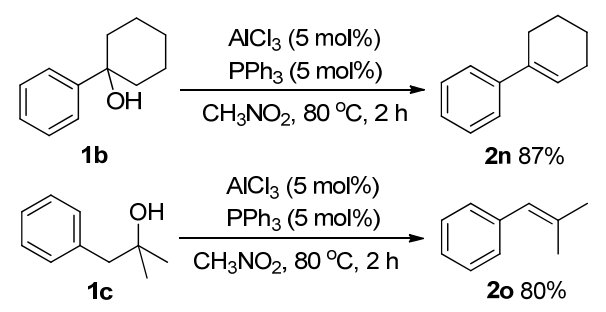

Scheme 1. $\mathrm{AlCl}_{3} / \mathrm{PPh}_{3}$-catalyzed dehydration of $\mathbf{1 b}$ and $\mathbf{1 c}$.

formation of the undesirable by-product 3a. The dimerization tri-substituted alkene mechanism of formation is known to proceed in the presence of an acid catalyst through the following two pathways: (1) coupling of benzylic alcohols and styrenes, in which the styrene components act as $\pi$-type nucleophiles [46,47]; (2) dimerization of $\mathbf{2 a}$ [48]. The two reaction pathways described to form $\mathbf{3 a}$ and the dehydration of $\mathbf{1 a}$ to $\mathbf{2 a}$ have been reported to be associated with the formation of a benzyl cation (I) (Scheme 2) [49,50]. A well-established mechanism shows the benzyl cation, in the presence of the strong Lewis acid, $\mathrm{AlCl}_{3}$, to form from either 1a or $2 \mathbf{a}$; a $\beta-\mathrm{H}^{+}$elimination of I leads to the formation of $\mathbf{2 a}$; the trapping of I with $\mathbf{2 a}$ results in the formation of $3 \mathbf{a}$. The positive effect of $\mathrm{PPh}_{3}$ on the $\mathrm{AlCl}_{3}$-catalyzed formation of $\mathbf{2 a}$ via dehydration of $\mathbf{1 a}$ should be linked to one or more reaction steps, in which the addition of $\mathrm{PPh}_{3}$ results in a change to either the reaction rate or the stability of intermediate species.

To better understand the mechanism behind how $\mathrm{PPh}_{3}$ enhances the $\mathrm{AlCl}_{3}$ catalyst, further control experiments were performed. Initially, $\mathrm{AlCl}_{3}$-catalyzed dimerization of $\mathbf{2 a}$ was examined in the presence or absence of $\mathrm{PPh}_{3}$. The dimerization reaction of $2 \mathrm{a}$ was observed to be significantly inhibited in the presence of $\mathrm{PPh}_{3}$ (Scheme 3). This result implies that, in the presence of $\mathrm{PPh}_{3}$, the enhanced catalytic activity of $\mathrm{AlCl}_{3}$ in promoting the dimerization of $\mathbf{2 a}$ was diminished, thus improving the chemical stability of $\mathbf{2 a}$ in the reaction system. The effect of $\mathrm{PPh}_{3}$ on the $\mathrm{AlCl}_{3}$ catalyst was also examined in the reaction of $1 \mathbf{a}$ with 1,1-diphenylethylene $\mathbf{4 a}$, which is known to be an active $\pi$-nucleophile, however, inert toward the dimerization reaction [51]. With $\mathrm{AlCl}_{3}$ alone, the Friedel-Crafts-type alkylation product $\mathbf{3 b}$ was isolated in $62 \%$ yield along with the formation of $22 \%$ of $3 \mathbf{a}$. There was no discernible detection of $\mathbf{2 a}$ in this system. In the presence of $\mathrm{PPh}_{3}$, the formation of $\mathbf{3 a}$ was totally suppressed, and additionally, the yield of $\mathbf{3 b}$ decreased to $36 \%$. However, 2a could be isolated in $41 \%$ yield. These results implied that the addition of $\mathrm{PPh}_{3}$ had a detrimental effect on the Friedel-Crafts-type reaction of $\mathbf{1 a}$ and $\mathbf{4 a}$.

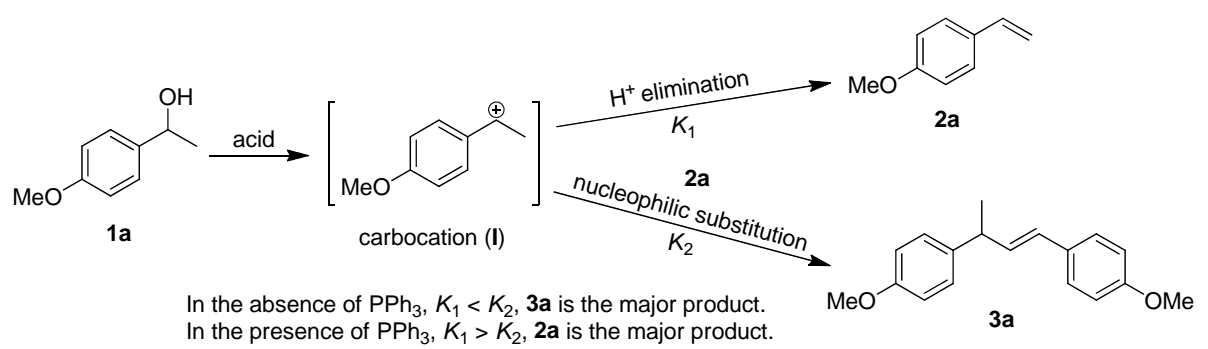

Scheme 2. Possible reasons behind the effect of $\mathrm{PPh}_{3}$ on the $\mathrm{AlCl}_{3}$ catalyst. 


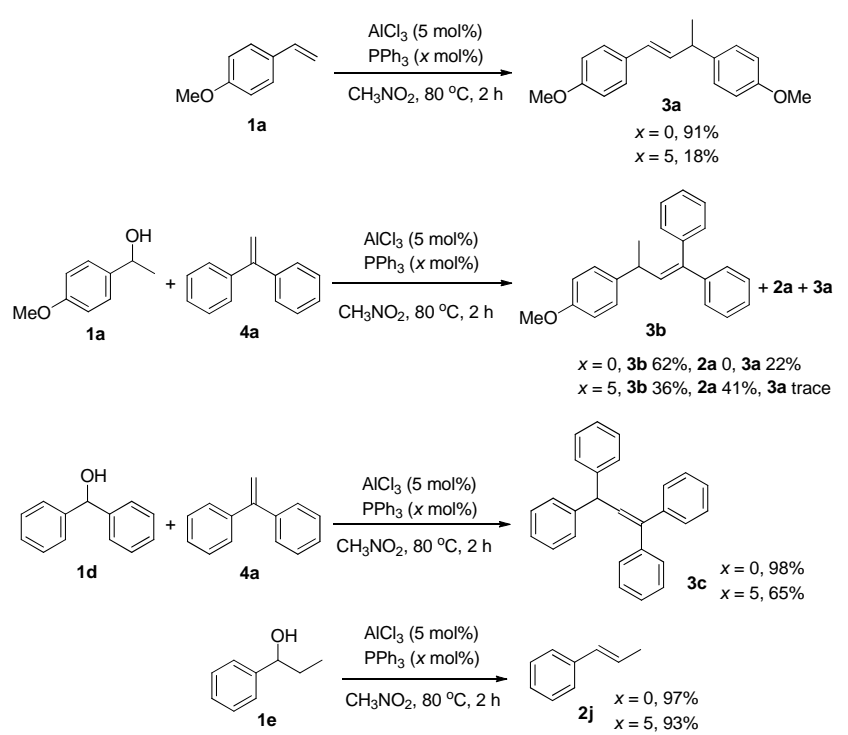

Scheme 3. Control experiments.

However, the formation reaction of $\mathbf{2 a}$ benefited from the use of $\mathrm{PPh}_{3}$. Further control experiments were performed including the $\mathrm{AlCl}_{3}$-catalyzed coupling reaction of benzhydrol $\mathbf{1 d}$ with $\mathbf{4 a}$. As the benzyl cation generated from $\mathbf{1 d}$ is chemically inert toward $\beta-\mathrm{H}^{+}$elimination, the results were expected to directly reflect the effect of $\mathrm{PPh}_{3}$ on the $\mathrm{AlCl}_{3}$-catalyzed Friedel-Crafts alkylation of $\mathbf{4 a}$. It is not a surprise to observe that $\mathrm{AlCl}_{3}$ is an excellent catalyst for promoting such a reaction, and the expected tri-substituted alkene $3 \mathbf{c}$ was formed in $98 \%$ yield after $2 \mathrm{~h}$ of reaction. However, after the addition of $\mathrm{PPh}_{3}$, the yield of 3c significantly decreased to 65\%. Considering unreacted 4 a can be recovered, we therefore concluded that the $\mathrm{PPh}_{3}$ Lewis base was effective in decreasing the rate of the FriedelCrafts-type nucleophilic substitution reaction. Finally, dehydration of 1-phenylpropanol 1e was investigated. The poor nucleophilicity of the generated product, 1-phenyl-1-propene $\mathbf{2} \mathbf{j}$ resulted in suppression of its corresponding dimer being formed. Therefore, this reaction can directly reflect the effect of $\mathrm{PPh}_{3}$ on the $\mathrm{AlCl}_{3}$-catalyzed dehydration of 2-arylethanol. Furthermore, it was evidenced that the yield of $\mathbf{2} \mathbf{j}$ decreased from $97 \%$ to $93 \%$ in the presence of $\mathrm{PPh}_{3}$ in the reaction system. This result indicated that the addition of $\mathrm{PPh}_{3}$ has no significant effect on benzyl cation intermediate formation and the subsequent $\beta$ - $\mathrm{H}^{+}$elimination step.

Collectively, all the results detailed provided an improved understanding as to circumvent the promoting effect of $\mathrm{PPh}_{3}$ on the $\mathrm{AlCl}_{3}$-catalyzed dehydration of $\mathbf{1 a}$. In the absence of $\mathrm{PPh}_{3}$, the reaction rate to form $\mathbf{3 a}$ is faster than $\mathrm{H}^{+}$elimination. Therefore, $\mathbf{3 a}$ is the major product. The presence of $\mathrm{PPh}_{3}$ likely decreases both the rates of nucleophilic substitution and $\beta-\mathrm{H}^{+}$ elimination. However, the likelihood is for a more significant drop in the rate of the former reaction. Therefore, the $\mathrm{H}^{+}$elimination reaction is relatively faster than $\mathbf{3 a}$ formation (Scheme 2) giving rise to a significant change of product distribution-hence the dramatic improvement of selectivity to $\mathbf{2 a}$.

The carbocation intermediate can be stabilized by polar and aprotic solvents, such as nitromethane, acetonitrile and di-

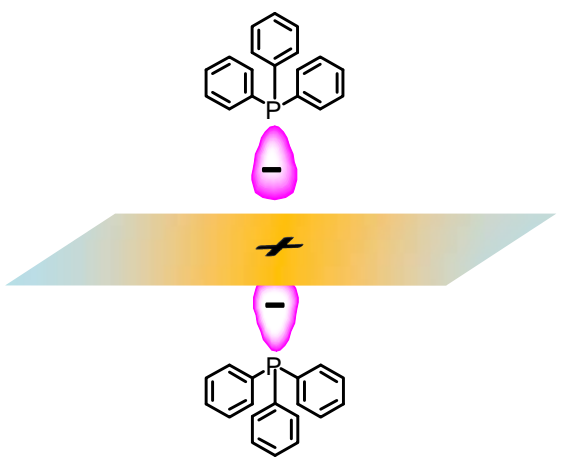

Scheme 4. Possible carbocation (I) interaction with $\mathrm{PPh}_{3}$.

chloromethane [52-55]. The intrinsic electrostatic interaction between the carbocation and the negative center of the solvent molecule is responsible for this stabilization effect. In the presence of $\mathrm{PPh}_{3}$, the generated benzyl cation (I) may interact preferentially with $\mathrm{PPh}_{3}$ because of the existence of a lone pair of electrons (Scheme 4). Such interaction types not only ensures improved stability of I, but additionally blocks access of the nucleophile to I, which slows the rate of the Friedel-Crafts-type nucleophilic substitution reaction. As $\beta-\mathrm{H}^{+}$elimination follows an E1 mechanism (single molecular reaction), it is not significantly affected by this type of interaction.

Reviewing the results in hand led to consideration of downstream applications of this Lewis base-assisted Lewis acid-catalyzed alkene formation via dehydration of alcohols. 2-Cinnamyl-1,3-dicarbonyl compounds are important synthons for organic synthesis [56,57]. The synthesis of such compounds is therefore a very active research topic. The reported methods hitherto can be categorized into the following four routes: (1) nucleophilic substitution of cinnamyl halides with 1,3-dicarbonyl compounds under basic conditions [58,59]; (2) acid-catalyzed direct C2-allylation of 1,3-dicarbonyl compounds with cinnamyl alcohols or their esters [60,61]; (3) Pd-catalyzed Trost-Tsuji reactions of cinnamyl carbonate or acetates [62]; similar reactions have also been reported using $\mathrm{Pt} /$ pyrrolidine as the catalyst [63]; and (4) direct allylic alkylation of 1,3-dicarbonyl compounds with alkenes via $\mathrm{Pd}(\mathrm{II})$-catalyzed allylic $\mathrm{C}-\mathrm{H}$ activation [64]. Although various routes to synthesize 2-cinnamyl-1,3-dicarbonyl compounds have been reported, those methods suffer from limitations of substrate generality, the availability of starting materials, multistep synthesis, use of expensive catalysts, the requirement of ligands or additives, low product yields, and the need for harsh synthesis conditions. Therefore, the design of improved and efficient approaches that allow for the rapid, cost-effective synthesis of 2-cinnamyl-1,3-dicarbonyl compounds from readily available precursors is highly desired.

Conversely, 2-aryl-3,4-dihydropyrans are known to be easily synthesized through a three-component reaction of styrene, 1,3-dicarbonyl compounds and formaldehyde in water in the absence of any catalyst $[65,66]$. Such widely accessible compounds led us to explore the possibility of their use in organic synthesis as building blocks [67-70]. Unexpectedly, 2-phenyl3,4-dihydropyran 5a can be converted to 2-cinnamyl-1,3-di- 


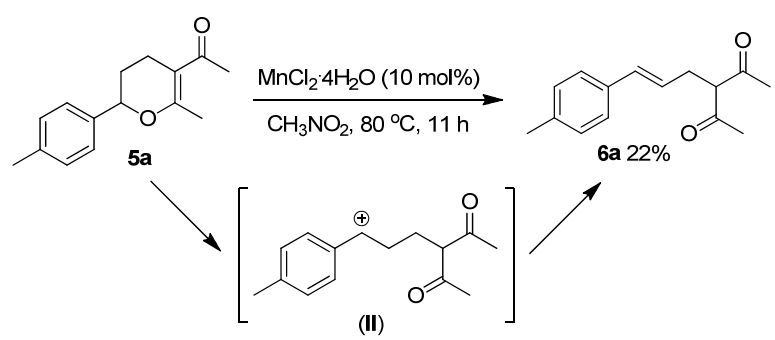

Scheme 5. Synthesis of $\mathbf{6 a}$ from $\mathbf{5 a}$.

carbonyl compound $\mathbf{6 a}$ in the presence of the mild Lewis acid, $\mathrm{MnCl}_{2}$. Unfortunately, the yield is minimal (Scheme 5). This transformation was theoretically triggered by the acid-catalyzed cleavage of an endocyclic $\mathrm{C}-\mathrm{O}$ bond of the 3,4-dihydropyran, which led to the formation of a benzylic cation (II). The following $\beta-\mathrm{H}^{+}$elimination of the carbocation intermediate resulted in the formation of $\mathbf{6 a}$. We speculate that the potential nucleophilicity of the 1,3-dicarbonyl fragment is partially responsible for the low yield of this reaction, which enabled intramolecular and intermolecular trapping of the benzylic cation to be possible, thus decreasing the reaction selectivity of $\mathbf{6 a}$ formation.

The strategy of the above-mentioned Lewis base-assisted Lewis acid-catalyzed alkene formation via alcohol dehydration was taken and applied to improve the yield of this reaction. However, the $\mathrm{AlCl}_{3} / \mathrm{PPh}_{3}$ system was observed to be inappropriate for this reaction to proceed efficiently (Table 3, entry 1). Further screening the reaction parameters found that the common Lewis acid, $\mathrm{I}_{2}$, in the presence of $\mathrm{PPh}_{3}$ resulted in significant conversion of $\mathbf{5 a}$ to $\mathbf{6 a}$ yielding $88 \%$ in $\mathrm{CH}_{3} \mathrm{NO}_{2}$ (entry 2). In the absence of $\mathrm{PPh}_{3}$, only $23 \%$ yield was obtained (entry 3). Multiple organic bases were examined, with $\mathrm{PPh}_{3}$ proving to be the most efficient (entries 4-8). The $\mathrm{I}_{2} / \mathrm{PPh}_{3}$ reaction system could be scaled up to multigram quantities yielding similar conversions (entry 9). This system can be further extended to convert various other dihydropyran derivatives (Scheme 6). Given the large number of commercially available 1,3-dicarbonyl compounds, which act as starting reagents, together with

Table 3

Synthesis of $\mathbf{6 a}$ from $\mathbf{5 a}$ over various Lewis acid/Lewis base combined catalysts.

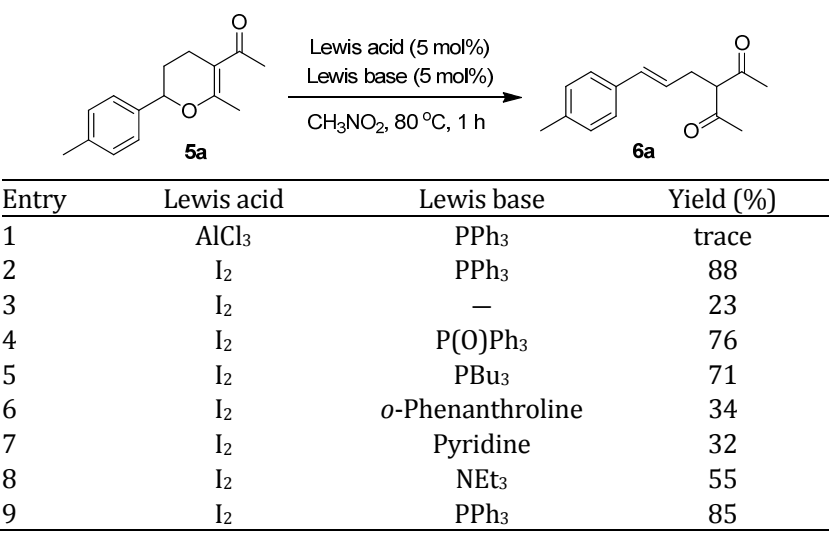

Reaction conditions: 5a $0.2 \mathrm{mmol}$, Lewis acid $0.01 \mathrm{mmol}$, Lewis base $0.01 \mathrm{mmol}$, solvent $\mathrm{CH}_{3} \mathrm{NO}_{2}, 1.0 \mathrm{~mL}, 80^{\circ} \mathrm{C}, 2 \mathrm{~h}$.
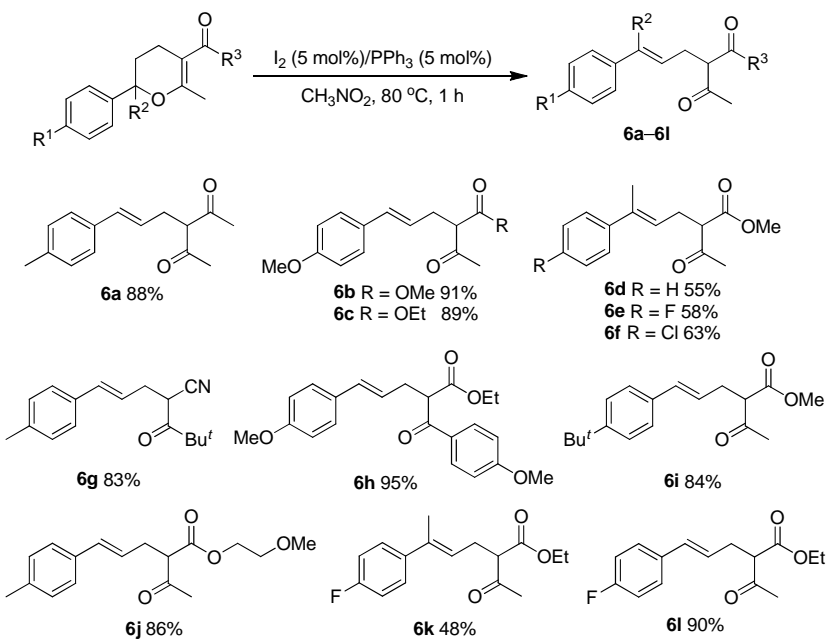

Scheme 6. Substrate scope of dihydropyran ring-opening reactions over an $\mathrm{I}_{2} / \mathrm{PPh}_{3}$ system.

the dihydropyran derivative ease of preparation, this synergistic protocol was expected to be a practically useful method to synthesize 2-cinnamyl-1,3-dicarbonyl compounds.

\section{Conclusions}

A combination of Lewis acids and Lewis bases was demonstrated to be effective for enhancing the selectivity of alkenes via alcohol dehydration. The addition of $\mathrm{PPh}_{3}$ into the $\mathrm{AlCl}_{3}$ catalyst system suppressed the formation of by-products, enabling improved dehydration efficiency of 1-arylethanols to styrenes. Further extending this unique synergistic effect, a selective transformation of 2-aryl-3,4-dihydropyrans to 2-cinnamyl1,3-dicarbonyl was also developed using $\mathrm{I}_{2} / \mathrm{PPh}_{3}$ as a combined catalyst. Given the fact that 2-aryl-3,4-dihydropyrans can be easily prepared from inexpensive chemicals under environmentally benign conditions, together with wide access to $I_{2}$ and $\mathrm{PPh}_{3}$, it is feasible that this method may be widely used for the industrial synthesis of 2-cinnamyl-1,3-dicarbonyl compounds. Evidencing the synergistic effect between Lewis acids and Lewis bases, further efficient synthetic methodologies may be discovered, and we are actively working on this topic.

\section{References}

[1] A. Molnar, M. Bartok, in: R. A. Sheldon, H. Van Bekkum eds, Fine Chemicals through Heterogeneous Catalysis, Wiley-VCH, Weinheim, 2001, 295.

[2] J. K. F. Buijink, J. P. Lange, A. N. R. Bos, A. D. Horton, F. G. M. Niele, in: S. T. Oyama ed, Mechanisms in Homogeneous and Heterogeneous Epoxidation Catalysis, Elsevier B. V., Amsterdam, 2008, 355.

[3] J. P. Lange, V. Otten, Ind. Eng. Chem. Res., 2007, 46, 6899-6903.

[4] J. P. Perez Valencia, E. San Nicolas Sayans, Ind. Eng. Chem. Res., 2011, 50, 5485-5489.

[5] N. M. Bertero, A. F. Trasarti, C. R. Apesteguia, A. J. Marchi, Appl. Catal. A, 2013, 458, 28-38.

[6] Z. Hasan, J. S. Hwang, S. H. Jhung, Catal. Commun., 2012, 26, 30-33.

[7] N. M. Bertero, C. R. Apesteguia, A. J. Marchi, Catal. Commun., 2008, $10,261-265$. 
[8] T. J. Korstanje, J. T. B. H. Jastrzebski, R. J. M. Klein Gebbink, ChemSusChem, 2010, 3, 695-697.

[9] M. L. Kantam, P. L. Santhi, M. F. Siddiqui, Tetrahedron Lett., 1993, 34, 1185-1186.

[10] T. Nishiguchi, N. Machida, E. Yamamoto, Tetrahedron Lett., 1987, $28,4565-4568$.

[11] H. A. Kalviri, F. M. Kerton, Adv. Synth. Catal., 2011, 353, 3178-3186.

[12] Z. Zhu, J. H. Espenson, J. Org. Chem., 1996, 61, 324-328.

[13] C. H. Liu, M. Shen, B. B. Lai, A. Taheri, Y. L. Gu, ACS Comb. Sci., 2014, $16,652-660$.

[14] M. M. Heravi, T. Ahmadi, A. Fazeli, N. M. Kalkhorani, Curr. Org. Synth., 2015, 12, 328-357.

[15] A. Tarlani, A. Riahi, M. Abedini, M. M. Amini, J. Muzart, J. Mol. Catal. A, 2006, 260, 187-189.

[16] A. A. H. F. Lafi, S. K. Matam, H. A. Hodali, Ind. Eng. Chem. Res., 2015, 54, 3754-3760.

[17] D. Mochizuki, R. Sasaki, M. M. Maitani, M. Okamoto, E. Suzuki, Y. Wada, J. Catal., 2015, 323, 1-9.

[18] P. Vazquez, L. Pizzio, C. Caceres, M. Blanco, H. Thomas, E. Alesso, L. Finkielsztein, B. Lantãno, G. Moltrasio, J. Aguirre, J. Mol. Catal. A, 2000, 161, 223-232.

[19] E. C. Wijnbelt, E. H. Hekelaar, US Patent, 20100240939 A1, 2010.

[20] N. M. Bertero, A. F. Trasarti, C. R. Apesteguia, A. J. Marchi, Appl. Catal. A, 2013, 458, 28-38.

[21] Y. M. Wang, V. Ulrich, G. F. Donnelly, F. Lorenzini, A. C. Marr, P. C. Marr, ACS Sustain. Chem. Eng., 2015, 3, 792-796.

[22] J. A. Ma, D. Cahard, Angew. Chem. Int. Ed., 2004, 43, 4566-4583.

[23] A. G. Doyle, E. N. Jacobsen, Chem. Rev., 2007, 107, 5713-5743.

[24] S. Mukherjee, J. W. Yang, S. Hoffmann, B. List, Chem. Rev., 2007, 107, 5471-5569.

[25] M. Shibasaki, N. Yoshikawa, Chem. Rev., 2002, 102, 2187-2209.

[26] D. H. Paull, C. J. Abraham, M. T. Scerba, E. Alden-Danforth, T. Lectka, Acc. Chem. Res., 2008, 41, 655-663.

[27] M. Kanai, N. Kato, E. Ichikawa, M. Shibasaki, Synlett, 2005, 1491-1508.

[28] S. E. Denmark, G. L. Beutner, Angew. Chem. Int. Ed., 2008, 47, 1560-1638.

[29] H. Yamamoto, K. Futatsugi, Angew. Chem. Int. Ed., 2005, 44, 1924-1942.

[30] H. Yamamoto, K. Futatsugi, in: H. Yamamoto, K. Ishihara eds, Acid Catalysis in Modern Organic Synthesis, Wiley-VCH, Weinheim, 2008, 1.
[31] L. J. Min, B. Pan, Y. L. Gu, Org. Lett., 2016, 18, 364-367.

[32] C. H. Liu, L. Zhou, W. B. Huang, M. Wang, Y. L. Gu, Adv. Synth. Catal., 2016, 358, 900-918.

[33] S. Kamijo, Y. Yamamoto, in: M. Shibasaki, Y. Yamamoto eds, Multimetallic Catalysts in Organic Synthesis, Wiley-VCH, Weinheim, 2004, 1.

[34] H. Li, H. G. Wu, Q. Y. Zhang, J. Liu, X. F. Liu, Y. C. Liu, S. Yang, Curr. Catal., 2013, 2, 173-212.

[35] C. H. Liu, L. Zhou, D. Jiang, Y. L. Gu, Asian J. Org. Chem., 2016, 5, 367-372.

[36] H. Morimoto, T. Yoshino, T. Yukawa, G. Lu, S. Matsunaga, M. Shibasaki, Angew. Chem. Int. Ed., 2008, 47, 9125-9129.

[37] S. E. Denmark, Y. Ueki, Organometallics, 2013, 32, 6631-6634.

[38] R. Yazaki, N. Kumagai, M. Shibasaki, J. Am. Chem. Soc., 2010, 132, 5522-5531.

[39] D. Uraguchi, N. Kinoshita, D. Nakashima, T. Ooi, Chem. Sci., 2012, 3, 3161-3164.

[40] C. H. Liu, A. Taheri, B. B. Lai, Y. L. Gu, Catal. Sci. Technol., 2015, 5, 234-245.

[41] M. H. Li, Y. L. Gu, Adv. Synth. Catal., 2012, 354, 2484-2494.

[42] Z. Q. Liu, Y. X. Zhang, L. X. Zhao, Z. J. Li, J. T. Wang, H. J. Li, L. M. Wu, Org. Lett., 2011, 13, 2208-2211.

[43] A. Taheri, C. H. Liu, B. B. Lai, C. Cheng, X. J. Pan, Y. L. Gu, Green Chem., 2014, 16, 3715-3719.

[44] K. X. Zeng, Z. P. Huang, J. Yang, Y. L. Gu, Chin. J. Catal., 2015, 36, 1606-1613.

[45] A. Taheri, B. B. Lai, C. Cheng, Y. L. Gu, Green Chem., 2015, 17, 812-816.

[46] J. R. Cabrero-Antonino, A. Leyva-Perez, A. Corma, Chem. Eur. J., 2013, 19, 8627-8633.

[47] N. G .Grigor'eva, S. V. Bubennov, L. M. Khalilov, B. I. Kutepov, Appl. Catal. A, 2011, 407, 85-90.

[48] T. J. Korstanje, J. T. B. H. Jastrzebski, R. J. M. Klein Gebbink, Chem. Eur. J., 2013, 19, 13224-13234.

[49] T. Aoyama, S. Koda, Y. Takeyoshi, T. Ito, T. Takido, M. Kodomari, Chem. Commun., 2013, 49, 6605-6607.

[50] F. Han, L. Yang, Z. Li, Y. W. Zhao, C. G. Xia, Adv. Synth. Catal., 2014, 356, 2506-2516.

[51] A. Taheri, X. J. Pan, C. H. Liu, Y. L. Gu, ChemSusChem, 2014, 7, 2094-2098.

[52] W. Yang, L. L. Huang, H. Liu, W. Wang, H. Li, Chem. Commun., 2013, 49, 4667-4669.

[53] R. Nallagonda, R. R. Reddy, P. Ghorai, Chem. Eur. J., 2015, 21,

\section{Graphical Abstract}

Chin. J. Catal., 2016, 37: 979-986 doi: 10.1016/S1872-2067(15)61084-1

\section{Lewis base-assisted Lewis acid-catalyzed selective alkene formation via alcohol dehydration and synthesis of 2-cinnamyl-1,3-dicarbonyl compounds from 2-aryl-3,4-dihydropyrans \\ Changhui Liu, Bin Pan, Yanlong Gu* \\ Huazhong University of Science and Technology; \\ Lanzhou Institute of Chemical Physics, Chinese Academy of Sciences}

To improve the reaction selectivity of dehydration of 1-phenylethanol, a novel Lewis base and Lewis acid synergistic catalytic system was developed. Alkenes and 2-cinnamyl-1,3-dicarbonyl derivatives were obtained in excellent yields under mild reaction conditions.

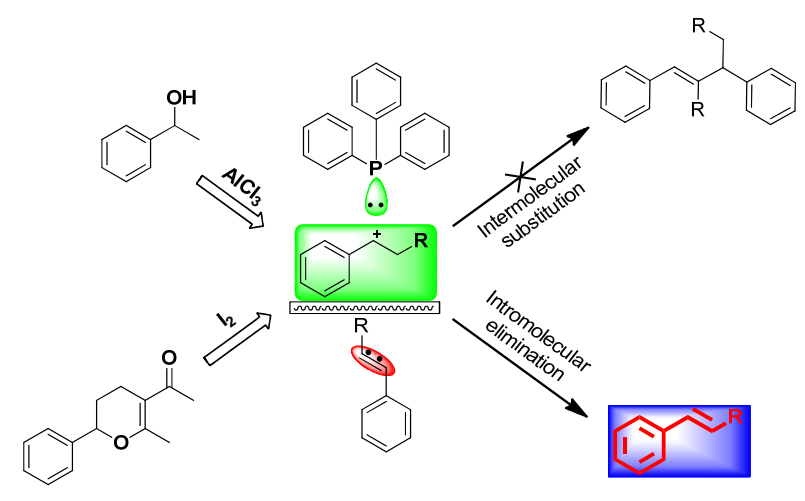


14732-14736.

[54] C. P. Wang, F. Ye, C. G. Wu, Y. Zhang, J. B. Wang, J. Org. Chem., 2015 80, 8748-8757.

[55] R. Panish, S. R. Chintala, D. T. Boruta, Y. Z. Fang, M. T. Taylor, J. M. Fox, J. Am. Chem. Soc., 2013, 135, 9283-9286.

[56] T. Cuvigny, M. Julia, J. Organometal. Chem., 1987, 331, 121-137.

[57] C. M. Qin, H. M. L. Davies, Org. Lett., 2013, 15, 310-313.

[58] M. Yasuda, T. Somyo, A. Baba, Angew. Chem. Int. Ed., 2006, 45, 793-796.

[59] M. Rueping, B. J. Nachtsheim, A. Kuenkel, Org. Lett., 2007, 9, 825-828.

[60] J. Tsuji, I. Shimizu, I. Minami, Y. Ohashi, T. Sugiura, K. Takahashi, J. Org. Chem., 1985, 50, 1523-1529.

[61] G. Giambastiani, G. Poli, J. Org. Chem., 1998, 63, 9608-9609.

[62] T. Mitsudome, K. Nose, K. Mori, T. Mizugaki, K. Ebitani, K. Kitsukawa, K. Kaneda, Angew. Chem. Int. Ed., 2007, 46, 3288-
3290.

[63] R. Shibuya, L. Lin, Y. Nakahara, K. Mashima, T. Ohshima, Angew. Chem. Int. Ed., 2014, 53, 4377-4381.

[64] S. Lin, C. X. Song, G. X. Cai, W. H. Wang, Z. J. Shi, J. Am. Chem. Soc., 2008, 130, 12901-12903.

[65] Y. L. Gu, J. Barrault, F. Jerome, Adv. Synth. Catal., 2009, 351, 3269-3278.

[66] Y. L. Gu, R. De Sousa, G. Frapper, C. Bachmann, J. Barrault, F. Jerome, Green Chem., 2009, 11, 1968-1972.

[67] M. H. Li, A. Taheri, M. Liu, S. H. Sun, Y. L. Gu, Adv. Synth. Catal., 2014, 356, 537-556.

[68] M. H. Li, C. H. Tang, J. Yang, Y. L. Gu, Chem. Commun., 2011, 47, 4529-4531.

[69] M. H. Li, Y. L. Gu, Tetrahedron, 2011, 67, 8314-8320.

[70] Y. J. Ren, M. H. Li, J. Yang, J. J. Peng, Y. L. Gu, Adv. Synth. Catal., 2011, $353,3473-3484$.

\section{Lewis 碱协助的 Lewis 酸催化醇脱水合成烯烃及二氢吡喃开环合成 2-肉桂基取代 1,3-二羰基化合物}

刘昌会 ${ }^{\mathrm{a}}$, 潘 涁 ${ }^{\mathrm{a}}$, 顾彦龙 ${ }^{\mathrm{a}, \mathrm{b}, *}$

a 华中科技大学能量转化与存储材料化学教育部重点实验室, 材料化学与服务失效湖北省重点实验室, 湖北武汉 430074

b 中国科学院兰州化学物理研究所羰基合成与选择性氧化国家重点实验室, 甘肃兰州 730000

摘要: 醇脱水是合成烯烃的重要方法之一. 全球每年约有 $15 \%$ 的苯乙烯是通过1-苯乙醇在酸性条件下脱水反应生产. 虽然 人们对该反应进行了较为深入的研究, 但是当使用活性较高的1-苯乙醇衍生物为底物时, 由于得到的取代苯乙烯产物具有 较高的反应性, 在脱水过程中会发生聚合而导致反应选择性降低, 因此有必要探索适宜在高活性1-苯基乙醇脱水反应中应 用的催化剂体系.

本文借助酸碱协同催化方法考察了1-(4-甲氧基苯基)乙醇制备 4-甲氧基苯乙烯的反应. 发现三苯基磷与 $\mathrm{AlCl}_{3}$ 构建的 Lewis 碱/Lewis 酸协同催化体系在硝基甲烷中可以接近定量的收率得到 4-甲氧基苯乙烯. Lewis碱/Lewis酸协同催化体系 有效避免了 4-甲氧基苯乙烯的二聚现象. 底物拓展研究显示该方法具有很好的底物普适性, 对多种取代苯乙烯的收率均超 过 80\%. 机理研究表明, 1-(4-甲氧基苯基)乙醇在酸作用下先生成碳正离子, 三苯基磷作为偶极性的电子给体不但能在一定 程度上稳定该苠基碳正离子, 而且抑制了其与4-甲氧基苯乙烯之间的亲电反应, 进而最大化了脱质子生成4-甲氧基苯乙烯 的选择性.

将Lewis 碱协助的 Lewis 酸催化提高反应选择性策略用于2-苯基-3,4-二氢吡喃衍生物合成2-肉桂基-1,3-二羰基化合物 的开环反应. 该类取代二氢吡喃在酸催化剂作用下也可生成苄基碳正离子, 但是该中间体易受分子间和分子内亲电反应 影响, 反应选择性不高. 而当使用单质碘/三苯基磷协同催化体系时, 2-苯基-3,4-二氢吡喃衍生物能高选择性地实现开环反 应, 得到反式 2-肉桂基-1,3-二羰基化合物. 该类1,3-二羰基化合物具有丰富的反应性, 是一类重要的合成子.

关键词：协同催化; 酸碱催化; 醇脱水; 2-肉桂基-1,3-二羰基化合物; 均相催化剂

收稿日期: 2016-02-05. 接受日期: 2016-03-15. 出版日期: 2016-06-05.

*通讯联系人. 电话: (027)87543732; 传真: (027)87544532; 电子信箱: klgyl@hust.edu.cn

基金来源：国家自然科学基金 (21173089，21373093); 中央高校基本科研业务费专项资金(2014ZZGH019); 湖北省催化化学协同 创新中心.

本文的英文电子版由Elsevier出版社在ScienceDirect上出版(http://www.sciencedirect.com/science/journal/18722067). 